\title{
Marek REWIZORSKI
}

Koszalin

\section{Globalizacja i jej przeciwnicy}

\section{Wstęp}

$\mathbf{W}$ ostatnich trzydziestu latach jedną z konsekwencji przyspieszonego rozwoju ekonomiczno-społecznego charakteryzującego się m.in. rewolucją technologiczną, zwiększeniem się płynności kapitału, liberalizacją handlu i homogenizacją kultury globalnej, jest powstanie ruchów społecznych sprzeciwiających się panującym obecnie w ekonomice światowej zasadom neoliberalizmu w wydaniu F. von Hayeka i M. Friedmana. Charakterystyczne cechy tychże ruchów społecznych (anty- i alterglobalistów) to samodzielność działania, znaczny stopień świadomości osiaganych celów, wspólnota idei oraz przekonań. Głównym punktem odniesienia dla ich działań jest globalizacja rozumiana jako proces odbywający się równolegle na wielu płaszczyznach, najczęściej: gospodarczej, społecznej, politycznej, kulturowej, informacyjnej i ekologicznej. Anty- i alterglobaliści różnią się nie tylko w zakresie opisu rzeczywistości, spory dotyczą także sposobów oddziaływania globalizacji na społeczne otoczenie człowieka, choć jedni i drudzy zauważają takie zjawiska, jak narastający konsumpcjonizm, niekontrolowany przez państwa rozrost korporacji transnarodowych, instytucjonalizację ubóstwa w krajach trzeciego świata, „westernizację” kultury, a także podział świata na bogatych i biednych, czyli „Północ” i „Południe”. Podstawę ideową obu wskazanych wyżej ruchów społecznych stanowią różnorodne koncepcje. Do najważniejszych można zaliczyć: pacyfizm, marksizm, socjalizm, anarchizm, ekologizm, libertarianizm, feminizm, konserwatyzm, a niejednokrotnie też fasadowy liberalizm.

Celem niniejszego artykułu jest przedstawienie głównych postulatów stawianych przez grupy kontestujące globalizację, zwłaszcza w kontekście asymetrii w rozwoju pomiędzy państwowymi aktorami stosunków międzynarodowych. Podjęcie tej tematyki jest istotne ze względu na fakt, że państwa rozwijające się, a w szczególności gospodarki wschodzące należące do grupy BRIC (Brazylia, Rosja, Indie, Chiny), stanowią coraz większą siłę w międzynarodowych stosunkach gospodarczych, wobec relatywnego spadku znaczenia wąsko rozumianej triady (USA, UE, Japonia). Anty- i alterglobaliści stanowią dla państw słabiej rozwiniętych niejednokrotnie zaplecze ideologiczne, którego sprawne wykorzystanie daje tym krajom - w oczach światowej opinii publicznej - znaczną przewagę nad państwami bogatymi. Uwidocznienie w ich postulatach konfliktu na linii „Północ-Południe” stanowi ponadto preludium do dyskusji o roli i funkcjach instytucji międzynarodowych, takich jak WTO czy Bank Światowy, które w opinii antyglobalistów, działających w zdecentralizowanych organizacyjnie strukturach pozarządowych, są niczym innym jak narzędziem dominacji państw bogatych nad biednymi.

\section{Główne założenia programu anty- i alterglobalistów}

Antyglobaliści jako ruch społeczny stanowią odpowiedź na tendencje globalizacyjne we współczesnym świecie. Jego początki są związane z konferencją WTO w Seattle (1999 r.), 
gdzie około 50 tysięcy demonstrantów, rekrutujących się spośród różnych grup o szerokim spektrum działania (od anarchistów po ekologów) doprowadziło do zamieszek uzasadnianych sprzeciwem wobec dyktatu światowych instytucji finansowych. W ramy ruchu antyglobalistycznego wpisuje się szereg organizacji pozarządowych funkcjonujących na pograniczu działalności państwa i instytucji międzynarodowych. Od lat 80. ubiegłego wieku zauważalne jest stałe zwiększanie ich liczby, którą obecnie szacuje się na ponad 30 tysięcy. Głównym celem antyglobalistów jest redystrybucja dochodów w skali globalnej na korzyść krajów rozwijających się. Ruch ten wyraża także sprzeciw wobec globalizacji rozumianej jako wyższa forma ustroju kapitalistycznego, umożliwiająca realizację interesów krajów bogatych. Wśród ugrupowań antyglobalistycznych warto wymienić np. Konfederację Chłopską we Francji, Ruch Ludzi bez Ziemi w Brazylii, a także Akcję Pomocy Obywatelskiej na rzecz Podatku Tobina (np. ATTAC ${ }^{1}$ we Francji) ${ }^{2}$. W opinii przeciwników globalizmu wpływy z tego podatku mogłyby zostać przeznaczone na poprawę sytuacji gospodarczej krajów rozwijających się. Innymi pomysłami na zmniejszenie dystansu ekonomicznego tych ostatnich wobec państw wysoko uprzemysłowionych są: wyłączenie rolnictwa z kompetencji WTO, podniesienie ceł i środków pozacelnych na towary rolno-spożywcze, zakaz subsydiowania ich eksportu przez kraje bogate. Za najbardziej radykalny postulat antyglobalistów należałoby uznać próbę ustanowienia zdecentralizowanego systemu rządów, w którym władza należałaby do „zwykłych ludzi”, a reguły jej sprawowania określałyby organizacje przyczyniające się do wzrostu dobrostanu społecznego (takie jak Światowa Organizacja Zdrowia czy Międzynarodowa Organizacja Pracy) kosztem WTO, MFW i Banku Światowego, które utraciłyby w takim stanie rzeczy dotychczasowe wpływy ${ }^{3}$.

Wśród ruchów społecznych krytycznie nastawionych wobec globalizacji coraz większe znaczenie odgrywa też alterglobalizm. Przedstawiciele tego nurtu myślenia, w przeciwieństwie do antyglobalistów, nie odrzucają programowo globalizacji, ale starają się spojrzeć na nią z perspektywy ogólnospołecznej, nie tylko ekonomicznej. Widać to w wypowiedzi jednego z najbardziej wpływowych przedstawicieli alterglobalizmu J. E. Stigliza, którego zdaniem, ,nie możemy cofnąć globalizacji; zadomowiła się w naszym życiu na dobre. Problem polega na tym, jak sprawić, żeby należycie przebiegała. A jeśli ma przebiegać należycie, to muszą istnieć globalne instytucji publiczne, które by pomogły w ustanowieniu jej zasad"4. Ruch alterglobalistów powstał w 2001 r. po Światowym Forum Społecznym (ang. World Social Forum) mającym miejsce w brazylijskim Porto Alegre ${ }^{5}$. Na szczycie przebiegającym pod hasłem ,Inny świat jest możliwy” głównym założeniem było jak największe zbliżenie do siebie różnych odłamów ruchów antyglobalistycznych. Jak można sądzić, bezpośrednim tego powodem była nieskuteczność tradycyjnych wystąpień przeciwko globali-

1 „ATTAC” - Obywatelska Inicjatywa Opodatkowania Obrotu Kapitałowego (fr. Association pour la Taxation des Transactions pour l'Aide aux Citoyens) to międzynarodowy ruch społeczny, utworzony w grudniu 1998 r. w Paryżu, mający pierwotnie na celu propagowanie wprowadzenia podatku Tobina. Do innych jego postulatów zalicza się najczęściej: likwidację rajów podatkowych, odrzucenie układu GATS, sprzeciw wobec Traktatu Lizbońskiego, zmianę zasad kredytowania państw trzeciego świata.

${ }^{2}$ Termin,,podatek Tobina” nawiązuje do nazwiska amerykańskiego ekonomisty, laureata nagrody Nobla w 1972 r., który wysunął propozycję wprowadzenia podatku od ruchów kapitałowych na rynkach walutowych, celem ograniczenia ich niestałości, co miało zapobiegać kryzysom walutowym. W ujęciu antyglobalistów podatek ten miałby stanowić instrument przeciwdziałania nadużyciom ekonomii liberalnej.

${ }^{3}$ B. Guillochon, Globalizacja. Jeden świat-różne drogi rozwoju, Wrocław 2003, s. 72.

${ }^{4}$ J. E. Stiglitz, Globalizacja, PWN, Warszawa 2006, s. 198.

${ }^{5} \mathrm{~W}$ spotkaniu tym uczestniczyło ponad 10 tys. osób. 
zacji, które miały raczej charakter starć z siłami bezpieczeństwa niż konstruktywnego dialogu ze zwolennikami wspomnianego procesu. Do najważniejszych założeń alterglobalizmu należą:

— pluralizm ideologiczno-światopoglądowy jego przedstawicieli;

- odejście od idealistycznego dążenia do zatrzymania globalizacji i jej negacji na rzecz pozytywistycznego założenia o wykorzystywaniu jej dla rozpowszechniania i ochrony praw człowieka oraz zapobiegania degradacji środowiska naturalnego;

- popieranie harmonizowania rynków i gospodarek w celu powiązania mechanizmów ekonomicznych z potrzebami społecznymi;

- wykorzystanie zdobyczy techniki dla budowy społeczeństwa obywatelskiego;

- odrzucenie determinizmu przy ocenie szans rozwojowych społeczeństw i krajów, co oznacza przekonanie o wpływie jednostki lub grupy społecznej (np. ruchu społecznego) na rozwój kraju, regionu, świata;

— brak zgody na „czarno-białą” wizję rozwoju gospodarki światowej proponowaną przez myśl neoliberalną (globalizacja i wolny rynek albo społeczny chaos i katastrofa ekologiczna);

- poparcie dla inicjatyw mających na celu integrowanie i rozwój lokalnych społeczności, które - nie będąc zmuszone do odrzucenia odrębności w sferach kultury, tradycji, historii i języka - mogą jednocześnie przejąć pozytywne aspekty globalizacji (np. korzystać z nowoczesnej techniki) w myśl zasady: myśl globalnie, działaj lokalnie.

Przedstawione wyżej najważniejsze punkty programu alterglobalistów składają się na ogólną, ale umiarkowanie spójną wizję rozwoju społeczeństwa doby globalizacji. Jak podkreśla J. Stiglitz, rynkowy fundamentalizm zakłada, że rynek może rozwiazać wszelkie problemy, a to bład. Neoliberalna globalizacja i brak bezpieczeństwa socjalnego prowadza do wzrostu przemocy $w$ świecie ${ }^{6}$. Wynika z tego, że społeczeństwo powinno dążyć do podporządkowania sobie procesów globalizacyjnych, mając na względzie zapewnienie funkcjonowania społeczeństwa obywatelskiego. Podobne stanowisko zajął papież Jan Paweł II, który w przemówieniu wygłoszonym 27 kwietnia 2000 r. podczas audiencji dla uczestników sesji plenarnej Papieskiej Akademii Nauk, stwierdził: W encyklice „, Centissimus annus" zauważyłem, że gospodarka rynkowa stanowi sposób właściwej odpowiedzi na potrzeby gospodarcze ludzi, szanujac wolna inicjatywe, ale musi być kontrolowana przez wspólnotę, posiadajacq wspólne dobro. Obecnie, gdy handel i komunikacja sq ponadgraniczne, to właśnie powszechne dobro wspólne domaga się tego, by logice właściwej rynkowi towarzyszyty mechanizmy kontrolne. Jest to zasadnicza sprawa dla uniknięcia redukowania wszystkich relacji społecznych do czynników ekonomicznych, a także w celu ochrony tych, którzy padli ofiara nowych form wykluczenia lub marginalizacji ${ }^{7}$. Ogólnie rzecz biorąc przedmiotem krytyki ze strony anty- i alterglobalistów są zjawiska towarzyszące globalizacji przebiegającej zgodnie z paradygmatem neoliberalnym. Przedstawiono je niżej na rysunku 1.

\footnotetext{
${ }^{6}$ Btyszczqca gwiazda Stiglitza, „Gazeta Wyborcza” z 22.01.2004 r.

${ }^{7}$ Cyt. za: J. Skubiszewska, Społeczne ruchy antyglobalizacyjne, Biuletyn, PISM, Seria Z, 2001, nr 31, s. 385 .
} 


\section{Kultura:}

- zanikanie kultur lokalnych,

- unifikacja kultury (macdonaldyzacja),

- narastanie konfliktów na tle narodowościowym i etnicznym

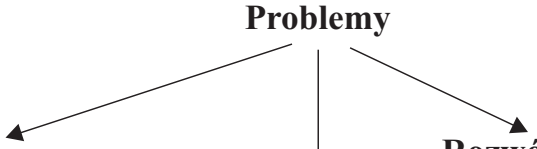

Rozwój krajów Trzeciego Świata:

- wyzysk pracowników przez KTN-y

- analfabetyzm i ubóstwo

- ograniczony dostęp do informacji

- monokulturowość gospodarek

- niewystarczające inwestycje w wiedzę

\section{Ekologia:}

szybko postępująca degradacja środowiska

Rys. 1. Kwestie najczęściej poddawane krytyce przez anty- i alterglobalistów

Źródło: Opracowanie własne.

\section{Spoleczna krytyka globalizacji i jej uzasadnienie}

Anty- i alterglobaliści, protestując przeciwko rosnącemu znaczeniu korporacji transnarodowych i stopniowemu przesuwaniu się punktu ciężkości w gospodarce światowej z suwerennych państw na instytucje o charakterze regionalnym, ponadregionalnym bądź ogólnoświatowym, zauważają globalny kryzys legitymizacji systemu rządów demokratycznych i groźbę zastąpienia go przez silnie zinstytucjonalizowane struktury technokratyczne (WTO, MFW, Bank Światowy, Komisja Europejska). Negatywnej ocenie podlegają także współczesne procesy ekonomiczne oparte na zasadach sformułowanych przez M. Friedmana i F. von Hayeka, zgodnie z którymi priorytetem w międzynarodowych stosunkach gospodarczych powinno być utrzymanie prymatu ekonomii nad polityką. W szczególności krytykowane są poglądy skrajnych neoliberałów, zbliżone do stanowiska amerykańskiego ekonomisty E. Luttwaka. Wprowadził on do języka ekonomicznego termin „turbokapitalizm”, który oznacza najbardziej rozwinięta, postindustrialną formę kapitalizmu, w której punktem centralnym jest efektywność rynkowa prowadząca do osiągnięcia jak największego zysku ${ }^{8}$. Jego osiagnięcie przy zastosowaniu neoliberalnych reguł w gospodarce prowadzi do powstania ogromnych kosztów społecznych, do których należy zaliczyć m.in. wzrost strukturalnego bezrobocia w krajach trzeciego świata oraz coraz bardziej widoczne rozwarstwienie społeczne w obrębie poszczególnych państw. Zdaniem N. Chomskiego, jednego z najbardziej znanych aktywistów międzynarodówki antyglobalistycznej, neoliberalizm to ,socjalizm dla bogatych", w którym - jak zauważa B. Barber - dominuje nurt uniwersalizującego amerykanizmu, forsowanego przez międzynarodowe instytucje i deprecjonującego pozycję suwerennych państw. Zdaniem tego autora nawet najbardziej rozwinięte $i$ samowystarczalne, zdawałoby się, państwa nie moga już pretendować do petnej suwerenności $i^{9}$. Towarzyszy temu zacieranie się odrębności i standaryzacja kultury (macdonaldyzacja), napędzana poprzez zanikanie różnicy pomiędzy kulturą wysoką a kulturą masową wykorzystywaną przez

\footnotetext{
${ }^{8}$ Por. E. Luttwak, Turbokapitalizm, Zwycięzcy i przegrani światowej gospodarki, Wyd. Dolnośląskie, Wrocław 2000 .

${ }^{9}$ B. R. Barber, Dżihad kontra McŚwiat, Warszawa 2001, s. 17.
} 
znane marki. Zdaniem Z. Baumana rozważania nad globalizacją prowadzą nieuchronnie do pytania o kondycję współczesnego człowieka, żyjącego w zglobalizowanej, sztucznej przestrzeni, którą można porównać do panoptycznego modelu nowoczesnej władzy Michela Foucaulta $^{10}$. Zgodnie z koncepcją tego autora o władzy, którą nadzorcy ukryci w centralnej wieży Panopticonu (będącego więzieniem) mają nad więźniami przetrzymywanymi w skrzydłach wzniesionej na planie gwiazdy budowli, decyduje połączenie dwóch faktów. Po pierwsze więźniowie są w pełni i zawsze widzialni, podczas gdy nadzorców w żadnym razie nie można zobaczyć. Po drugie więźniowie żyją w poczuciu ciągłej niepewności, nie są bowiem w stanie stwierdzić, czy są w określonym momencie obserwowani, co sprawia, że muszą cały czas zachowywać się tak, jakby w danej chwili znajdowali się pod bezpośrednim nadzorem ${ }^{11}$. Podstawowym założeniem tej koncepcji jest stwierdzenie, że zarówno strażnicy, jak i więźniowie żyją w tej samej przestrzeni, jednakże wyłącznie pierwsza z wymienionych grup jest w stanie poznać rzeczywistość, natomiast druga ,porusza się we mgle”. Odnosząc tę koncepcję do sposobu postrzegania świata przez antyglobalistów - niewidocznymi, z punktu widzenia grupy więźniów-konsumentów, strażnikami są potężne przedsiębiorstwa posiadające filie w wielu państwach, a także instytucje międzynarodowe takie jak MFW, WTO i Bank Światowy. Naomi Klein, autorka książki No Logo uważanej za biblię antyglobalistów zauważa, iż: w zamian za globalny świat musieliśmy zrzec się wyboru. Teraz o tym, co wartościowe w kulturze, decyduja stacje telewizyjne $i$ studia filmowe. Marketing zastapił nam gust ${ }^{12}$. Według niej o społecznym i gospodarczym obliczu gospodarki decydują KTN-y, które - jak odnotował w 1983 r. T. Levitt, - nie mogą akceptować lokalnych obyczajów, ale muszą dążyć do homogenizacji potrzeb i pragnień całego świata. Jego zdaniem korporacja globalna operuje, zachowujac niezachwianq stałość - przy niskich kosztach własnych - tak jakby cały świat (albo jego najważniejsze regiony) stanowity spójnq, niezróżnicowanq całość; wszędzie sprzedaje to samo $i$ w ten sam sposób. [...] Dawne różnice narodowych gustów czy sposobów prowadzenia interesów znikaja ${ }^{13}$. Taki stan rzeczy, tj. promowanie homogenicznego image'u przez głównie amerykańskie korporacje, wspierane pop-kulturowymi wizerunkami reklamowymi (np. kowboj Marlboro, świąteczny wystrój w reklamie Coca-Coli) postawiło znak równości pomiędzy globalizacją a marketingiem. Z drugiej strony wywołało opór przeciwko amerykańskiemu imperializmowi kulturowemu, którego symbolem dla wielu przeciwników globalizacji stała się postać francuskiego antyglobalisty José Bové’a, współautora znanej książki Świat nie jest towarem. W trwającej od połowy lat 70. działalności Bové aktywnie występował przeciwko korporacjom transnarodowym, głosząc hasło ,powrotu do natury” i niejednokrotnie uciekając się do aktów nieposłuszeństwa obywatelskiego ${ }^{14}$. Przykładowo był on jednym z inicjatorów akcji skoszenia pól z genetycznie modyfikowaną kukurydzą (1998 r.

${ }^{10}$ Panopticon jest ideą wysuniętą przez myśliciela angielskiego J. Benthama.

${ }^{11}$ Z. Bauman, Globalizacja. I co z tego dla ludzi wynika, Warszawa 2000, s. 43.

12 Cytowane za: L. Gawor, Antyglobalizm, Alterglobalizm i filozofia zrównoważonego rozwoju jako globalizacyjne perspektywy, „Problemy ekorozwoju” 2006, vol. 1, nr 1, s. 43.

${ }^{13}$ N. Klein, No logo, Izabelin 2004, s. 134.

${ }^{14} \mathrm{~W}$ pierwszej połowie lat 70. Bové sprzeciwiał się planom rozbudowy bazy wojskowej w okolicach Larzac (z 3 do 17 tys. hektarów). We współdziałaniu z miejscowymi rolnikami oraz aktywistami o antykorporacyjnych poglądach utworzył sieć 200 komitetów we Francji, Niemczech i Wielkiej Brytanii. Ponadto sprzeciwiając się planom militaryzacji francuskiej prowincji wraz z setkami protestujących, rozpoczął na terenie planowanej bazy budowę zagrody dla owiec. Akcja ta trwająca w latach 1973-1975, została określona jako „manifestation en dur”. Zimą 1975/1976 Bove, uchylając się przed obowiązkiem odbycia służby wojskowej, wyjechał z Larzac do położonej w Pirenejach miejscowości Montredon, osiadając tam na pewien czas jako rolnik. 
- Nérac, 2006 r. - Miradoux), a także zniszczenia budowy lokalnej restauracji McDonald's w Millau (1999 r.). W 1999 r. protestował przeciwko zasadom handlu produktami rolnymi, negocjowanym na konferencji WTO w Seattle. Założył ponadto ruch społeczny o nazwie Konfederacja Chłopska (Confédération Paysanne, 1987), którego głównym celem jest reprezentowanie interesów europejskich rolników wobec banków i firm z sektora rolnego, a także przeciwdziałanie skutkom tzw. rolnictwa intensywnego, wyrażającego się w stosowaniu metod produkcji rolnej mogących spowodować zagrożenia dla zdrowia konsumentów oraz lokalnych ekosystemów. Pomimo podejmowania przez niego działań niejednokrotnie wykraczających poza obowiązujące ramy prawne, zdołał zwrócić uwagę międzynarodowej opinii publicznej na zagrożenia globalizacji, takie jak: stosowanie genetycznie zmodyfikowanej żywności (Bové wprowadził określenie La malbouffe - podłe żarcie) serwowanej w fast-foodach typu McDonald's, zagrożenia dla drobnych producentów rolnych wynikające z internacjonalizacji działalności przedsiębiorstw sektora rolnego czy amerykanizacja kultury światowej ${ }^{15}$.

Rdzeń ideowy ruchu anty- i alterglobalistów stanowią postulaty o charakterze ekonomicznym, uzasadniane poprzez powoływanie się na stanowisko niektórych przedstawicieli nauk społecznych. Szczególne znaczenie dla kształtowania się mają tutaj poglądy amerykańskiego socjologa R. Sennetta, które w początkowej wersji zostały sformułowanie w jego znanej książce The Fall of Public Man (1977). Zdaniem tego autora kryzys finansowy, rozwijajacy się szybko od 2007 r., jest zwiastunem końca kapitalizmu w jego obecnej formie. Wedtug Senneta we współczesnym ,turbokapitalizmie” istnieje niemożliwa do zasypania przepaść pomiędzy grupq wysoko wyspecjalizowanych pracowników majacych szansę szybko się bogacić oraz ogromna rzesza ludzi zbędnych, dla których wyzwolenie z rutyny dawnego fabrycznego kapitalizmu jest ,, skokiem w pustkę”, ponieważ ich umiejętności nie daja im żadnych perspek$t y w^{16}$. Antyglobaliści, wychodząc poza „turbokapitalistyczną” wizję T. Luttwaka, która jest ich zdaniem swoistą pułapką zastawioną na kraje rozwijające się, wskazują równocześnie na zagrożenie wynikające z rozpadu systemu kapitalistycznego, zgodnie z tezą R. Senneta. W rezultacie może dojść do sytuacji, w której ani bogaci, ani biedni nie odniosą korzyści, a jedynie straty (z ang. no win-win world). Sprzeciwiając się takiej perspektywie, wskazują na istnienie trzeciej drogi opartej na filozofii zrównoważonego rozwoju (ang. sustainable development). Idea ta, wykształcona w latach 80-tych XX w. na bazie krytycznych raportów ONZ o stanie współczesnej cywilizacji, to typ rozwoju społeczno-ekonomicznego, którego podstawę stanowi osiągnięcie równowagi ekonomicznej, społecznej i ekologicznej.

Szczególnie dużą wagę anty- i alterglobaliści przykładają do problemów ekonomicznych, koncentrując się na sytuacji gospodarczej w krajach „Południa”. W ich opinii konieczne jest odrzucenie w gospodarce światowej motywu zysku, który jest siłą napędową globalizacji, a także zmiana polityki społecznej w kierunku zapewnienia gwarancji zatrudnienia i osłon specjalnych dla najuboższych warstw ludności. Do najważniejszych postulatów ekonomicznych należą:

— wyrównanie szans państw bogatych i biednych w zakresie dostępu do globalnego pieniądza, kredytu, inwestycji, a także korzystania ze stref offshore;

- opodatkowanie międzynarodowego kapitału (podatek Tobina) w celu pomocy krajom biednym;

15 J. Bové, A Farmers' International?, „New Left Review”, November-December 2001, http://newleftreview.org/A2358.

${ }^{16}$ Niech banki plajtuja! A my twórzmy nowe miejsca pracy, wywiad z R. Sennetem, „Dziennik”, 28.02.2009 r. 
— zwiększenie wpływu krajów rozwijających się na działalność najważniejszych organizacji międzynarodowych;

- wprowadzenie reguł odpowiedzialności prawnej i finansowej korporacji transnarodowych i silniejsze niż dotąd podporządkowanie ich działalności państwom;

— umorzenie długu krajom Trzeciego Świata.

Podnosząc kwestię zlikwidowania nierówności pomiędzy krajami „Północy” i „Południa”, anty- i alterglobaliści wskazują jednocześnie na szereg problemów cząstkowych, które zagregowane tworzą obraz globalizacji nierówności, a zatem takiego ukształtowania stosunków gospodarczych w skali globalnej, które mają charakter trwały i asymetryczny. Krytyce poddaje się w szczególności triadę instytucji globalnych WTO, MFW i Bank Światowy. Ataki na WTO są najczęściej związane z tezą o odebraniu krajom rozwijającym się możliwości prowadzenia własnej polityki handlowej jako instrumentu rozwoju oraz brakiem legitymizacji demokratycznej samej organizacji. Jako uzasadnienie wskazuje się przykładowo na negatywne skutki obwiązywania Porozumienia w sprawie handlowych aspektów praw własności intelektualnej (TRIPS) wpływającego na powiększenie się różnic rozwojowych między członkami $\mathrm{WTO}^{17}$. Zdaniem antyglobalistów i przedstawicieli krajów biednych, te ostatnie, podpisując wskazaną wyżej umowę, nie zdawały sobie sprawy z jej implikacji. Wspomniane wyżej porozumienie, przyjęte pod presją światowych koncernów farmaceutycznych, spowodowało znaczy wzrost kosztów dostępu do leków i zaawansowanych technologii medycznych dla krajów rozwijających się, a jednocześnie doprowadziło do stałego transferowania zysków z patentów, praw autorskich i znaków towarowych dla krajów bogatych. Nastąiła zatem paradoksalna sytuacja, w której korzyści płynące z wykorzystywania plantacji wielu roślin leczniczych, znajdujących się w krajach rozwijających się, przypadły tzw. bioprospektorom, wywodzącym się z krajów Północy i kontrolującym patenty na materiał genetyczny ${ }^{18}$.

Krytyce poddawany jest także oligarchiczny, zdaniem anty- i alterglobalistów, system podejmowania decyzji w WTO. Podkreśla się przy tym, że bardziej demokratyczne procedury obowiązywały w GATT (jeden kraj - jeden głos). System ten został zmieniony pod koniec lat 50., kiedy consensus zastąpiono dyktatem państw Quadu (USA, Japonia, UE, Kanada). Doprowadziło to do sytuacji, w której obecnie w WTO najważniejsze decyzje podejmowane są na nieformalnych, kuluarowych sesjach i przedstawiane pozostałym państwom jako fakt dokonany. Prowadzenie tego rodzaju działań potwierdziła Charlene Barshefsky, reprezentantka USA podczas zakończonej niepowodzeniem Konferencji Ministerialnej w Seattle. Opisując procedurę podejmowania decyzji na szczytach negocjacyjnych WTO zauważyła, że przyjmowano je w ograniczonym gronie 20-30 kluczowych państw, co wywoływało wrażenie, jakby pozostali członkowie WTO zostali postawieni poza procesem negocjacji1 ${ }^{19}$.

Przedmiotem krytyki anty- i alterglobalistów są także negatywne efekty działania MFW i Banku Światowego wobec krajów rozwijających się. Według J. Cavanagha, S. Retallck i C. Welch, MFW od czasu „kryzysu zadłużeniowego” lat 80. sprawuje neokolonialną kontrolę nad krajami rozwijającymi się, posługując się przy tym programami dostosowawczymi (z ang. Structure Adjustment Programs - SAPs). Fundusz zazwyczaj narzuca krajom bied-

\footnotetext{
${ }^{17}$ Pogląd ten został wyrażony m.in. w: The TRIPS Agreement and Developing Countries, United Nations Conference on Trade and Development, Geneva 1996; K. E. Maskus, Intellectual Property Rights in the Global Economy, Institute for International Economics, Washington, DC 2000.

18 J. A. Scholte, Globalizacja, Sosnowiec 2006, s. 377.

${ }^{19}$ W. Bello, Stużenie bogatym - a nie biednym, w: Czy globalizacja pomaga biednym?, Raport Międzynarodowego Forum ds. Globalizacji, Łódź 2003, s. 33-34.
} 
nym pakiet zmian strukturalnych w ich gospodarkach narodowych, co prowadzi do łatwego dostępu korporacji transnarodowych z „Północy” do taniej siły roboczej i zasobów naturalnych. Proces eksploatacji finansowej i gospodarczej państw biednych jest dodatkowo przyspieszony poprzez zmuszanie ich rządów do znoszenia ograniczeń w handlu i inwestycjach, promowania eksportu, dewaluowania waluty narodowej, podnoszenia stóp procentowych, prywatyzacji sektora publicznego, cięcia wydatków publicznych i liberalizacji rynku pracy ${ }^{20}$. Anty- i alterglobaliści podważają przede wszystkim skuteczność programów MFW, twierdząc, że w rzeczywistości przynoszą krajom potrzebującym więcej szkody niż pożytku m.in. dlatego, że nie są dostosowane do ich konkretnych potrzeb, a jedynie powielane według jednolitego neoliberalnego wzorca. Według byłego wiceprezesa Banku Światowego J. Stiglitza, skargi na narzucanie przez MFW warunków dotyczyty nie tylko ich rodzaju i sposobu narzucania, lecz również sposobu ich komunikowania. Standardowa procedura MFW polega na napisaniu projektu programu jeszcze przed przybyciem do kraju klienta. Przyjazd do danego kraju ma wyłacznie na celu dopracowanie programu i korektę rażacych btędów. W praktyce wspomniany projekt jest szablonem, z catymi paragrafami wyjętymi z programu dotyczacego jednego kraju $i$ wstawionymi do programu dla drugiego kraju ${ }^{21}$. Przeciwnicy globalizacji wskazują, że wdrażanie SAP-ów w krajach ubogich powoduje ogromne kłopoty wewnętrzne. Dla przykładu w Senegalu, który zdaniem MFW w latach 90-tych znajdował się w okresie wzrostu osiągniętego dzięki realizacji programów dostosowawczych, bezrobocie wzrosło z 25\% w 1991 r. do 44\% w 1996 r., w Zimbabwe od 1990 r., kiedy wprowadzono SAP, wydatki na zdrowie per capita uległy obniżeniu o 1/3, a w Kostaryce, pierwszym kraju Ameryki Środkowej, który wprowadził program MFW, płace realne spadły w latach 1980-1991 średnio o $16,9 \%{ }^{22}$.

W podobnym tonie wypowiada się N. Klein w książce Doktryna szoku. Autorka nie tylko atakuje kapitalizm w sposób właściwy wyżej wymienionym autorom, ale posuwa się znacznie dalej, podważając zasadność całej doktryny neoliberalnej w wersji przedstawionej przez Miltona Friedmana i jego uczniów (Chicago boys). W hipotezie badawczej wskazuje, iż liberalizm - będący w rzeczywistości emanacją amerykańskich strategii wolnorynkowych - podbija świat, wykorzystując to, że niektóre kraje i narody znajdują się w stanie szoku spowodowanego katastrofami naturalnymi (np. huragan Katrina, tsunami w Azji Południowo-Wschodniej) lub polityczno-gospodarczymi (wojskowy zamach stanu w Chile, masakra na placu Tiananmen, „Plan Balcerowicza” w Polsce $)^{23}$. Doktrynę szoku opisuje słowami, swojego nieżyjącego już od 2006 r. arcyadwersarza - Miltona Friedmana - który w jednym ze swoich dzieł z lat 80-tych dokładnie przedstawił taktykę, za pomocą której współczesny kapitalizm realizuje swoje cele. Cytowany przez autorkę Friedman dowodzi, że tylko kryzys - rzeczywisty lub postrzegany - prowadzi do realnych zmian. Kiedy taki kryzys nastapi, rodzaj podejmowanych działań będzie zależat od tego, jakie pomysty dominuja na rynku idei. I tutaj wtaśnie dostrzegam nasze najważniejsze zadanie. Musimy stworzyć alternatywy dla istniejacych rozwiqzań, mówić o nich i utrzymywać je przy życiu, aż pewnego dnia to, co politycznie niemożliwe, stanie się politycznie nieuniknione ${ }^{24}$. Wychodząc od koncepcji ,doktryny szoku”, Klein formułuje także pojęcie „kapitalizmu kataklizmowego”, który określa jako zorganizowane

\footnotetext{
${ }^{20}$ Op. cit., s. 21-22.

${ }^{21}$ J. Stigliz, op. cit., s. 57.

${ }^{22}$ Czy globalizacja pomaga..., op. cit., s. 23.

${ }^{23}$ N. Klein, Doktryna szoku, Warszawa 2009.

${ }^{24}$ M. Friedman, Capitalism and Freedom, University of Chicago Press, Chicago 1992, s. IX, w: op. cit., s. 13.
} 
ataki na sfere publiczna po rozmaitych katastrofach, w połaczeniu z traktowaniem tych katastrof jako świetnych okazji do ubicia interesu ${ }^{25}$. Autorka zauważa, że przejawy funkcjonowania „doktryny szoku”, której głównym orędownikiem w międzynarodowych stosunkach gospodarczych są USA i kontrolowany przez nie Międzynarodowy Fundusz Walutowy, występują nie tylko w krajach rozwijających się (Boliwia, Argentyna, Chile), ale także wśród gospodarek wschodzących (Chiny), krajów w okresie transformacji gospodarczej (Polska), a nawet mniej rozwiniętych regionów państw zaliczanych do ścisłej czołówki w ekonomice światowej.

Z polskiej perspektywy szczególnie interesujące są rozważania N. Klein dotyczące związków doktryny szoku z transformacją systemową w Polsce, zwaną potocznie „Planem Balcerowicza". Autorka zwraca uwagę na fakt, że w rzeczywistości autorem wspomnianego wyżej „planu” był amerykański doradca ekonomiczny Jeffrey Sachs, który ze względu na wiek (34 lata w 1989 r.), jednoczesną działalność doradczą w sześciu krajach oraz pełnione obowiązki akademickie został na początku lat 90 . ubiegłego wieku uznany przez prestiżowy „Los Angeles Times" za Indiane Jonesa Ekonomii ${ }^{26}$. Sachs, który zaczął pracować jako doradca „Solidarności”, namówił do współpracy miliardera i spekulanta Georga Sorosa oraz Davida Liptona, zwolennika wolnego rynku, zatrudnionego w MFW. W zamian za obietnicę udzielenia pożyczki przez MFW i umorzenia dużej części polskich długów udało mu się przeforsować - wbrew dużej części działaczy Solidarności - całościowy plan przejścia z gospodarki socjalistycznej do wolnego rynku, którego stworzenie, na co zwraca uwagę N. Klein, trwało jedną noc. Tym samym odrzucona została wizja rozwoju ekonomicznego zawarta w programie „Solidarności”, oparta na przekształceniu państwowych zakładów w kooperatywy, kontrolowane przez rade robotnicza, reprezentujace kolektyw i operacyjnie kierowane przez dyrektora, wytonionego $w$ drodze konkursu i kierowanego przez radę ${ }^{27}$. Podobnie jak w wypadku J. Stigliza wskazuje ona, że „terapia szokowa” nie była dostosowana do potrzeb polskich, ale stanowiła jedynie kalkę podobnych reform przeprowadzonych przez MFW w innych krajach.

Przedstawiciele ruchów opozycyjnych wobec globalizacji nie tylko krytykują działalność międzynarodowych instytucji, ale również wskazują na szereg negatywnych konsekwencji wspomnianego procesu dla krajów rozwijających się. Zwracają przykładowo uwagę na to, że obecny podział na „Północ” i „Południe” odzwierciedla określoną strukturę w światowych stosunkach społecznych. Ludziom z „Davos”, tj. mieszkańcom krajów zamożnych znacznie łatwiej osiagnąć sukces zawodowy niż mieszkańcom krajów słabiej rozwiniętych. Ci ostatni, na co zwraca uwagę B. Barber w książce Skonsumowani, w daleko mniejszym stopniu są globalnymi konsumentami. Zdaniem tego autora $w$ nowej epoce, w której ubodzy nie maja dochodów, a forsiaści nie maja potrzeb, skrajna nierówność jest po prostu zakładana z góry ${ }^{28}$. Dla przykładu w 2004 r. Stany Zjednoczone i Kanada, które zamieszkuje jedynie 5\% ludności świata, kontrolowały prawie jedną trzecią wydatków na konsumpcję prywatną. Podobnie było w przypadku Europy Zachodniej zamieszkiwanej wtedy przez około 6,4\% mieszkańców i kontrolującej prawie 30\% globalnych wydatków na konsumpcję. Skalę różnic w poziomie

\footnotetext{
${ }^{25}$ Ibidem, s. 12-13.

${ }^{26}$ J. Risen, Cowboy of Poland's Economy, „Los Angeles Times”, 9 lutego 1990.

27 Por. Program „Solidarności” przyjęty na pierwszym zjeździe krajowym, w: P. Reina, Poland 1981: Towards Social Renewal, George Allen \&Anwin, London 1985, s. 326-380.

${ }^{28}$ B. R. Barber, Skonsumowani. Jak rynek psuje dzieci, infantylizuje dorostych i potyka obywateli, Warszawa 2009, s. 20-21.
} 
konsumpcji pomiędzy „Północą a Południem” obrazował fakt, że Afryka Subsaharyjska, zamieszkiwana przez niemal $11 \%$ populacji świata posiadała bardzo skromny udział w wydatkach globalnych, tylko nieznacznie przekraczający $1 \%{ }^{29}$. Podobnie było w 2006 r., w którym - według danych przedstawionych w 2010 r. przez Worldwatch Institute - 65 państw o wysokim dochodzie kontrolowało około 78\% konsumpcji globalnej, podczas gdy zamieszkiwało je zaledwie $16 \%$ światowej populacji ${ }^{30}$. Najwięcej w stosunku rocznym wydali mieszkańcy USA - 9,7 bln USD (średnio 32400 dol. amerykańskich per capita). W 2006 r. Stany Zjednoczone kontrolowały $32 \%$ wydatków na świecie, przy populacji tego kraju stanowiącej około 5\% ludności świata. Jednakże, jak wskazują B. Barber oraz S. Pascala, tendencje do globalnego konsumeryzmu mogą zostać zahamowane i to niezależnie od woli samych konsumentów. Z pewnością w średniookresowej perspektywie negatywnie będą tu oddziaływać konsekwencje kryzysu finansowego, rozprzestrzeniającego się po świecie od 2007 r. Z kolei w perspektywie długoterminowej istotne znaczenie w ograniczeniu konsumpcji światowej mogą mieć problemy globalne o podłożu ekologicznym i ludnościowym.

Na pierwsze z nich zwraca uwagę Stephen Pascala - znawca problematyki środowiskowej z Princeton University. Podkreśla on, że $500 \mathrm{mln}$ ludzi o największym dochodzie na świecie (ok. 7\% populacji globalnej) jest odpowiedzialnych za 50\% emisji dwutlenku węgla, podczas gdy 3 miliardy najbiedniejszych mieszkańców Ziemi - jedynie za 6\%. W kontekście walki z ociepleniem klimatu staje się oczywiste, że państwa rozwinięte muszą dążyć do obniżenia wysokich poziomów konsumpcji. Gdyby bowiem wszyscy mieszkańcy naszej planety konsumowali jak mieszkańcy USA, wtedy byłaby ona w stanie „utrzymać” jedynie 1,4 mld ludzi ${ }^{31}$.

Z kolei B. Barber odnosi kwestię konsumeryzmu do problemu starzenia się mieszkańców świata rozwiniętego, którzy: [...] starzeja się z chronologicznego punktu widzenia, ale pod względem zachowania, stylu $i$ samodyscypliny sq coraz młodsi $i^{32}$. Autor ten stawia tezę, że na Zachodzie rynek konsumencki i sferę gustów opanowują dzieci, przez co podważają kulturę dorosłych. Jednakże ze względu na zmniejszający się przyrost naturalny możliwości ekspansji konsumpcyjnej w krajach bogatych są coraz bardziej ograniczone. Pod względem demograficznym znacznie bardziej dynamiczne są społeczeństwa krajów rozwijających się i potencjalnie właśnie tam znajduje się największa liczba konsumentów. W rzeczywistości jednak światowy kapitalizm ignoruje ich potrzeby, ponieważ dzieci te nie dysponuja dochoda$m i$, żeby zapłacić za ich zaspokojenie ${ }^{33}$. Barber słusznie zauważa, że nastoletni mieszkańcy krajów rozwijających się, spędzając większość dnia w fabrykach lub oddając się prostytucji, budują globalną gospodarkę rynkową, niewiele otrzymując w zamian. Sytuacji nie zmienia działalność Banku Światowego czy MFW, które przyznanie jakichkolwiek pożyczek obwarowują różnorakimi warunkami. Ewentualna odmowa udzielenia środków finansowych może w efekcie doprowadzić do utrwalenia nierówności pomiędzy konsumentami z „Północy” i „Południa”, która stawia kapitalizm przed dylematem. Polega on na tym, że rynek kapitalistyczny produkujący nadmiar towarów musi albo się rozwijać, albo zginąć. Jego rozwój może zostać poważnie zakłócony przez to, że ubodzy nie mogą wzbogacić się na tyle, by stać się

\footnotetext{
${ }^{29}$ State of the World 2004 report, tabela 1-1, Consumer spending and Population by Region, 7 stycznia 2004, www. Worldwatch.org/press/news/2004/01/07.

${ }^{30}$ State of the World 2010, Transforming Cultures: from Consumerism to Sustainability, Worldwatch Institute, New York-London 2010, s. 6.

${ }^{31}$ Ibidem.

${ }^{32}$ B. Barber, Skonsumowani ..., op. cit., s. 19.

${ }^{33}$ Ibidem.
} 
konsumentami, a bogaci mają co prawda niezbędne dochody, ale ze względu na wysoki poziom zaspokojenia swoich potrzeb, nie wykazują wystarczająco dużo woli, by kupować. Postawienie takiej diagnozy wskazuje na konieczność sztucznego kreowania potrzeb, infantylizowania dorosłych i wychowywania konsumentów poprzez kierowanie reklam już do dzieci i młodzieży. Problem w tym, że jest to głównie młodzież z Zachodu. Kreowanie potrzeb za pomocą reklamy, z pominięciem potencjalnych konsumentów z krajów rozwijających się, zamiast „zasypywać nierówności”, powiększa je i prowadzi do rzeczywistego ograniczenia globalizacji tylko do „Pierwszego Świata”. W efekcie wytworzony zostaje wirtualny świat potrzeb bogatych społeczeństw, których nie interesuje los trzech czwartych państw na świecie. Te ostatnie obejmuje globalizacja ubóstwa przypominająca raczej kolumbowską terra incognita niż obszar prawdziwego i szczerego zainteresowania państw rozwiniętych i instytucji międzynarodowych, powołanych do niesienia rzeczywistej pomocy potrzebującym jej ubogim krajom.

Anty- i alterglobaliści wskazują także, że te ostatnie są ,polem doświadczalnym” dla tzw. sweatshops - międzynarodowych korporacji wykorzystujących tanią siłę roboczą z krajów Trzeciego Świata, nieprzestrzegających prawa pracy, dewastujących lokalne ekosystemy, wspierających skorumpowane władze, łamiących prawa człowieka. Jednocześnie wskazuje się, iż niska świadomość powyższych zjawisk w krajach biednych jest spowodowana ograniczonym, w porównaniu do społeczeństw krajów bogatych, dostępem mieszkańców „Południa" do środków komunikowania się. Według raportu Narodów Zjednoczonych pod koniec lat 90 . kraje o najwyższych dochodach stanowiące tylko $1 / 5$ światowej populacji skupiały na swoim terenie $74 \%$ wszystkich linii telefonicznych, a równocześnie najbiedniejsza piąta część ludności dysponowała zaledwie $1,5 \%$ tychże linii ${ }^{34}$. Różnica w dostępie do zaawansowanych technologii i ich wykorzystaniu pomiędzy krajami biednymi a bogatymi jest przez niektórych autorów określana mianem ,luki cyfrowej” (z ang. digital divide). Jak wskazuje P. Norris w 2000 r. w krajach Afryki położonych na południe od Sahary liczba użytkowników sieci Internetu wynosiła $3 \mathrm{mln}$, podczas gdy w tym samym okresie w USA - $154 \mathrm{mln}^{35}$.

W opinii anty- i alterglobalistów państwa rozwijające się ustępują też krajom bogatym pod względem wielkości udziału w światowym eksporcie i imporcie, a ich mieszkańcy mają utrudniony dostęp do kapitału. Pomimo że większość tzw. rajów podatkowych (offshore) położona jest w krajach „Południa”, to korzyści z działalności tychże ośrodków finansowych płyną do mieszkańców z „Północy”, tzw. ,hinwis” (ang. high worth net individuals). W tabeli 1 zamieszczono najbardziej znane raje podatkowe na świecie.

Tabela 1

Raje finansowe na świecie

\begin{tabular}{||l|l||}
\hline \multicolumn{1}{|c|}{ Region } & \multicolumn{1}{c|}{ Raje finansowe } \\
\hline \multicolumn{1}{|c||}{} & \multicolumn{1}{c||}{2} \\
\hline Europa & Wyspa Man, Jersey, Guernsey, Liechtenstein, Sark, Gibraltar, Campione, Madera \\
\hline Bliski Wschód & Bahrajn, Dubaj \\
\hline Afryka Zachodnia & Liberia \\
\hline Ocean Indyjski & Seszele, Mauritius \\
\hline
\end{tabular}

${ }^{34}$ Human Development Report, London-New York 1999, s. 3.

${ }^{35}$ P. Norris, Digital Divide: Civic Engagement, Information Poverty, and the Internet Worldwide, Cambridge 2001, s. 47. 


\begin{tabular}{||l|l||}
\hline \multicolumn{1}{|c|}{1} & \multicolumn{1}{|c|}{2} \\
\hline Azja Południowo-Wschodnia & Xianggang, Hongkong, Makau, Labuan, Singapur \\
\hline Oceania & $\begin{array}{l}\text { Mariany Północne, Wyspy Marshalla, Nauru, Wyspy Cooka, Vanuatu, Samoa Za- } \\
\text { chodnie }\end{array}$ \\
\hline Karaiby & $\begin{array}{l}\text { Belize, Kajmany, Kostaryka, Panama, Antyle Holenderskie, Bermudy, Bahamy, } \\
\text { Turks, Caicos, Brytyjskie Wyspy Dziewicze, Anguilla, Antigua, Barbuda, Saint } \\
\text { Christopher, Nevis, Barbados, Saint Lucia, Saint Vincent, Grenadyny }\end{array}$ \\
\hline
\end{tabular}

Źródło: Opracowanie własne.

\section{Słabe strony $w$ argumentacji anty- i alterglobalistów}

Na marginesie podjętych rozważań warto zaznaczyć, że pomimo znacznej siły i trafności argumentacji, a także różnorodności tematyki podejmowanej przez anty- i alterglobalistów prezentowana przez nich wizja globalizacji gospodarczej jest trudna do zaakceptowania w całości i to z kilku powodów. J. Stiglitz, R. Kuttner, J. Gray, N. Klein, L. Wallach, N. Chomsky, B. Barber i inni krytycy globalizacji przedstawiają ją często jako rodzaj parareligijnego kultu czy inaczej rynkowego fundamentalizmu, dowodząc jednocześnie, że jest ona instrumentem dyktatu państw bogatych składającym się z trzech elementów: deregulacji, prywatyzacji i liberalizacji handlu. Błąd tego rozumowania wynika z bipolarnego postrzegania świata, w którym wszelka aktywność aktorów państwowych ogranicza się do rywalizacji pomiędzy zantagonizowanymi grupami państw. Takie ujęcie przypomina żywo myślenie o stosunkach międzynarodowych w kategoriach właściwych realizmowi politycznemu. Jest to o tyle zastanawiające, że w dominującym obecnie modelu stosunków międzynarodowych, określanym przez R. Keohane’a i J. Nye jako „kompleksowa współzależność”, państwa bezustannie rywalizując ze sobą, nie są w stanie zapewnić dla siebie stabilnego rozwoju politycznego i gospodarczego. Konieczne staje się zatem dążenie do współpracy, której warunkiem jest osiągnięcie kompromisu w najważniejszych sprawach. Ponieważ siłą napędową postępującego procesu globalizacji nie są wyłącznie dążenia państw, konieczne jest także współdziałanie z innymi podmiotami stosunków międzynarodowych, zwłaszcza z organizacjami międzynarodowymi. Anty- i alterglobliści zwracają niejednokrotnie uwagę na fakt, że organizacje takie jak WTO czy MFW nie spełniają funkcji pośrednika pomiędzy państwami biednymi i bogatymi, a jedynie pogłębiają nierówności pomiędzy nimi. Założenie to w świetle posiadanej wiedzy razi swoją ogólnością i narażone jest na zarzut nieprawdziwości. Świadczy o tym fakt, że każdy, nawet najmniejszy kraj, może zablokować rokowania handlowe, na co wskazuje przykład. tzw. „Cotton Four” - grupy czterech afrykańskich producentów bawełny, których nieustępliwe stanowisko było jedną z przyczyn fiaska konferencji WTO w Cancun (2003 r.) czy nowego rozdziału głosów w Międzynarodowym Funduszu Walutowym, w związku z którym w 2008 r. niektórzy członkowie grupy BRIC zwiększyli swój wpływ na jego decyzje kosztem tradycyjnie silnie reprezentowanych członków G8 na czele z USA. Krytyka globalizacji w wersji anty- i alterglobalistów jest niepełna, ponieważ najczęściej nie uwzględnia się w nich danych empirycznych, z których wynika, że to właśnie w okresie globalizowania gospodarki światowej (ostatnie 30 lat) ochrona socjalna w państwach bogatych jak również biednych osiagnęła nienotowany wcześniej poziom. Współczesny kapitalizm jest nie tylko do pogodzenia z ideą państwa socjalnego, ale nie może bez niej w pełni funkcjonować. Bierze się to stąd, że podstawowe gwarancje socjalne dla uboższych obywateli stanowią „wentyl bezpieczeństwa”, dający upust społecznym frustracjom wynikającym z nierów- 
nomiernego rozdziału własności prywatnej. Wydaje się też, że anty- i częściowo alterglobalizm obciążone są myśleniem ukierunkowanym bądź dążeniem ku idealizowaniu ,tego, co dobre w przeszłości" i opieraniu na tej podstawie wniosków co do teraźniejszości oraz przyszłości, bądź też oparte są na podważonych naukowo koncepcjach rozwoju społecznego. Przedstawianie procesów zachodzących w gospodarce światowej zgodnie $\mathrm{z}$ tezą sformułowana już w 1014 r. przez arcybiskupa Wulfstana, który oznajmił w jednym ze swych kazań, iż: świat pędzi do przodu i zbliża sięjego koniec ${ }^{36}$ jest jednostronne i nieprawdziwe tak samo, jak podtrzymywanie tezy o istnieniu „klas”, tj. klasy posiadającej - państw bogatych dysponujących środkami produkcji i klasy nieposiadającej - państw rozwijających się, które w wyniku pogłębiania globalizacji i funkcjonowania ponadpaństwowych podmiotów gospodarki światowej - tracą. Anty- i alerglobaliści, starając się przekonać opinię publiczną o trwałej i pogłębiającej się asymetrii rozwoju poszczególnych państw oraz ich grup w gospodarce światowej, powołują się na dane makroekonomiczne dotyczące np. wysokości stóp procentowych, poziomu bezrobocia, długu publicznego, deficytu budżetowego czy inflacji. Dane statystyczne, obok podbudowy ideologicznej, mają wzmocnić siłę ich argumentacji. Z drugiej strony również zwolennicy globalizmu są w stanie w taki sam sposób uzasadniać swoje stanowisko. Zdaniem J. Norberga antyglobaliści operują jedynie półprawdami, popartymi arbitralnie dobranymi danymi zebranymi w celu stawiania zazwyczaj kontrowersyjnych hipotez. Według tego autora w okresie 1965-1998 średni światowy dochód na mieszkańca wzrósł z 2497 do 4839 USD. W samych tylko państwach najbiedniejszych zwiększył się we wspomnianym okresie z 551 do 1137 USD, a zatem o ponad 100\%. Wiele krajów dokonało skoku cywilizacyjnego, wychodząc z zaklętego kręgu ubóstwa. W porównaniu z 1820 r., kiedy około 85\% światowej populacji żyło za mniej niż dolara dziennie, liczba ta spadała na początku lat 80 . ubiegłego wieku do $30 \%$. W ciągu ostatnich 30 lat odsetek ludzi głodujących zmniejszył się o połowę (w 1970 r. wynosił 37\%). Stopniowo zanika też wśród krajów rozwijających się zjawisko analfabetyzmu. O ile w 1925 r. na ich obszarze około 75\% mieszkańców nie potrafiło pisać i czytać, o tyle w 1970 r. wskaźnik ten obniżył się do $20 \%{ }^{37}$.

\section{Zakończenie}

Rola, jaką pełnią ruchy anty- i alterglobalistyczne jest w obecnym czasie niezwykle istotna, ponieważ stanowią one opozycję dla neoliberalizmu jako obowiązującej doktryny w ekonomice światowej. Nawołując do ustanowienia mechanizmów zapewniających sprawiedliwy podział dóbr pomiędzy „Północą” a „Południem”, przyczyniają się do internacjonalizacji zasady solidarnej współpracy państw, a przez to do zapewnienia ładu w gospodarce światowej. Ruchy te wspierają zatem ,słabszą stronę” w międzynarodowych stosunkach gospodarczych, - kraje rozwijające się. Negatywnym aspektem ich działalności jest jednakże postrzeganie globalizacji jako procesu podporządkowywania słabszych - silniejszym, a zatem oparcie się na idei walki klas w światowym systemie gospodarczym. Twierdzenie to trudno utrzymać w świetle aktualnej wiedzy ekonomicznej, według której relacje pomiędzy państwowymi aktorami w gospodarce światowej można rozpatrywać raczej w ramach modelu gier J. von Neumanna niż w kategoriach walki klasowej K. Marksa. Jak można sądzić, krytycy globalizacji

\footnotetext{
${ }^{36}$ Cyt za: A. Giddens, Runaway World: How Globalisation is Reshaping Our Lives, London 1999, s. 1.

${ }^{37}$ Dane statystyczne podane na podst.: J. Norberg, Spór o globalizację. Kto zyskuje, kto traci, ile i dlaczego?, Warszawa 2006, s. 26-38.
} 
nie posiadają monopolu na prawdę. Nie posiadają jej także zwolennicy globalizacji. Analizując niniejszy proces, anty- i alterglobaliści słusznie wskazują na istnienie ubóstwa na świecie. Jednakże nie dostrzegają lub pomijają w swoich rozważaniach szereg pozytywnych zmian, jakie zaszły na nim w ciągu ostatnich kilkudziesięciu lat. Powodem takiego stanowiska jest, być może, ogromna złożoność procesu globalizacji, który można rozpatrywać z wielu punktów widzenia.

\section{Bibliografia}

Barber B. R., Dzihad kontra McŚwiat, Warszawa 2001.

Barber B. R., Skonsumowani. Jak rynek psuje dzieci, infantylizuje dorostych i polyka obywateli, Warszawa 2009.

Bauman Z., Globalizacja. I co z tego dla ludzi wynika, Warszawa 2000.

Bello B., Stużenie bogatym - a nie biednym, w: Czy globalizacja pomaga biednym?, Raport Międzynarodowego Forum ds. Globalizacji, Łódź 2003.

Blyszczqca gwiazda Stiglitza, „Gazeta Wyborcza” z 22.01.2004.

Bové J., A Farmers' International?, „New Left Review”, November-December 2001, http://newleftreview.org/A2358.

Friedman M., Capitalism and Freedom, University of Chicago Press, Chicago 1992.

Gawor L., Antyglobalizm, alterglobalizm i filozofia zrównoważonego rozwoju jako globalizacyjne perspekty$w y$, „Problemy ekorozwoju” 2006, nr 1.

Giddens A., Runaway World: How Globalisation is Reshaping Our Lives, London 1999.

Guillochon B., Globalizacja. Jeden świat - różne drogi rozwoju, Wrocław 2003.

Human Development Report, London-New York 1999.

Klein N., Doktryna Szoku, Warszawa 2009.

Klein N., No logo, Izabelin 2004.

Luttwak E., Turbokapitalizm, Zwycięzcy i przegrani światowej gospodarki, Wyd. Dolnośląskie, Wrocław 2000.

Niech banki plajtuja! A my twórzmy nowe miejsca pracy, wywiad z R. Sennetem, „Dziennik”, 28.02.2009.

Norris P., Digital Divide: Civic Engagement, Information Poverty, and the Internet Worldwide, Cambridge 2001.

Maskus K. E., Intellectual Property Rights in the Global Economy, Institute for International Economics, Washington, DC 2000.

Norberg J., Spór o globalizację. Kto zyskuje, kto traci, ile i dlaczego?, Warszawa 2006.

Reina P., Poland 1981: Towards Social Renewal, George Allen \& Anwin, London 1985.

Risen J., Cowboy of Poland's Economy, „Los Angeles Times”, 9 lutego 1990.

Scholte J., Globalizacja, Warszawa 2006.

State of the World 2004 report, www.Worldwatch.org/press/news/2004/01/07

State of the World 2010, Transforming Cultures: from Consumerism to Sustainability, Worldwatch Institute, New York-London 2010.

\section{Summary}

One of the results of the accelerated economic and social development over the last thirty years involves the emergence of social movements that are opposed to globalization. The objective of this paper is to present the main demands of the opponents of globalization, in particular in the context of the asymmetrical development of the parties in international relations. 
Anti-globalists and alter-globalists oppose the increasing importance of transnational corporations and the gradual shift of the point of gravity in the global economy from sovereign states to institutions of a regional, supraregional or global character. Anti-globalists note the progressing global crisis of legitimization of the democratic system of governance and the threat that it will be replaced by highly institutionalized technocratic structures (WTO, IMF, World Bank, European Commission). The role of anti-globalist and alter-globalist movements is of profound significance at present as they provide opposition to neoliberalism as the binding doctrine in global economy. Calling for the establishment of mechanisms that would provide for fair distribution of goods between the 'North' and the 'South' they contribute to the internationalization of the idea of collaboration between states thus ensuring that order be maintained in the global economy. Therefore, these movements support the 'weaker party' in international business relations - the developing countries. However, there is a negative aspect of their activity, namely they perceive globalization as a process of subordinating the weak by the strong, or - in other words - they refer to the idea of class struggle in the global economic system. 
